\title{
Isolation and characterization of microsatellite loci in the Neotropical fish Astyanax altiparanae (Teleostei: Characiformes) and cross-species amplification
}

\author{
ROSÂNGELA LOPES ZAGANINI ${ }^{1}$, DIOGO TERUO HASHIMOTO ${ }^{1}$, LUIZ HENRIQUE GARCIA PEREIRA ${ }^{2}$, \\ CLAUDIO OLIVEIRA ${ }^{2}$, FERNANDO FERNANDES MENDONÇA ${ }^{2}$, FAUSTO FORESTI ${ }^{2}$ \\ and FÁBIO PORTO-FORESTI ${ }^{1 *}$ \\ ${ }^{1}$ Departamento de Ciências Biológicas, Faculdade de Ciências, Universidade Estadual Paulista, \\ Júlio de Mesquita Filho, 17033-360, Bauru, SP, Brazil \\ ${ }^{2}$ Departamento de Morfologia, Instituto de Biociências, Universidade Estadual Paulista, Júlio de Mesquita Filho, \\ 18618-000, Botucatu, SP, Brazil
}

\begin{abstract}
[Zaganini R. L., Hashimoto D. T., Pereira L. H. G., Oliveira C., Mendonça F. F., Foresti F. and Porto-Foresti F. 2012 Isolation and characterization of microsatellite loci in the Neotropical fish Astyanax altiparanae (Teleostei: Characiformes) and cross-species amplification. J. Genet. 91, e24-e27. Online only: http://www.ias.ac.in/jgenet/OnlineResources/91/e24.pdf]
\end{abstract}

\section{Introduction}

We isolated and characterized 11 polymorphic microsatellite loci from the Neotropical fish Astyanax altiparanae, considered of economic interest, whose stocks have been seriously endangered by the introduction of predatory fishes. The analyses in a population of 33 specimens detected a large number of alleles (ranging from 4 to 11) and high levels of heterozygosity $(0.64-0.88)$ at these loci, indicating their usefulness in population genetic studies. Cross-species amplification was successful only in species of Astyanax, $43 \%$ of which were polymorphic.

The Characiformes constitute one of the dominant and more diverse orders among tropical fishes, with more than 1800 species, among which the family Characidae is the most diverse, with species spread throughout the Neotropical region. However, the interrelationships among the Characidae are poorly known (Reis et al. 2003) and remain under discussion (Javonillo et al. 2010; Mirande 2010).

The genus Astyanax (Characiformes, Characidae) comprises 163 described species (Froese and Paulay 2010), and its systematics are very complex and several studies have currently shown that the genus needs to be more thoroughly characterized. A. altiparanae, encountered along the south and southeast Brazilian rivers, was formerly included in the complex 'A. bimaculatus' (Garutti and Britski 2000), which is widely distributed in South America. A. altiparanae is of great economic interest, also being utilized as bait in

\footnotetext{
*For correspondence. E-mail: fpforesti@fc.unesp.br.
}

sport fishing and in aquaculture programmes (Garutti and Britski 2000; Porto-Foresti et al. 2010). However, the stocks of this species are seriously endangered by introduced predatory fishes, such as tucunaré (Cichla spp.) and corvina (Plagioscion squamossissimus) (Agostinho et al. 2007).

Many molecular markers have been frequently used for the Astyanax species (Prioli et al. 2002; Leuzzi et al. 2004; Peres et al. 2005). However, there are no microsatellite data available for this group. These markers can be valuable tools to investigate genetic variability, with applications to conservation and population genetics (Oliveira et al. 2006). Their use in stock characterization of A. altiparanae may have practical implications for fisheries, fish farming, and conservation biology. We describe the isolation and characterization of 11 novel microsatellite loci from A. altiparanae, and their cross-amplification for potential utility in studies of additional species.

\section{Materials and methods}

A microsatellite-enriched genomic library was obtained for A. altiparanae following the protocol described by Billotte et al. (1999). Genomic DNA was extracted using the commercial Wizard Genomic DNA Purification kit (Promega, São Paulo, Brazil). The total DNA was digested with $R s a \mathrm{I}$ and enriched in $(\mathrm{AC})_{\mathrm{n}}$ and $(\mathrm{AG})_{\mathrm{n}}$ repeats. Enriched fragments were amplified by polymerase chain reaction (PCR) and then linked into a pGEM vector (Promega) and transformed into competent XL1-blue Escherichia coli cells. Positive colonies were tested by PCR to confirm the presence

Keywords. molecular markers; fish conservation; aquaculture; polymorphic DNA. 
of inserts. Selected recombinant colonies were sequenced using the primers T7 (5'-TAATACGACTCACTATAGGG$\left.3^{\prime}\right)$ and SP6 (5'-ATTTAGGTGACACTATAGAA-3') and the BigDye Terminator kit (Applied Biosystems, São Paulo, Brazil), and electrophoresed on an ABI Prism 377 automated sequencer (Applied Biosystems, Foster City, USA). Flanking primers were designed with Primer3 software (Rozen and Skaletsky 2000).

\section{Results and discussion}

We isolated and sequenced a total of 48 positive colonies, resulting in 25 good quality flanking sequences. The selected sequences were used to characterize a sample of 33 A. altiparanae specimens, collected in the Batalha river $\left(22^{\circ} 6^{\prime} 40.92^{\prime \prime} \mathrm{S}, 49^{\circ} 16^{\prime} 5.81^{\prime \prime} \mathrm{W}\right)$, Brazil, and tested in five individuals of the species Salminus brasiliensis, Brycon amazonicus, Brycon hilarii, A. fasciatus, A. bockmanni, A. paranae, A. abramis, A. schubarti, A. ribeirae and $A$. jacuhiensis. PCR was performed in $20 \mu \mathrm{L}$ reaction volume containing approximately $10.9 \mu \mathrm{L} \mathrm{H}_{2} \mathrm{O}$ miliQ, $2.75 \mu \mathrm{L}$ PCR buffer $10 \times, 1.25 \mu \mathrm{L} \mathrm{MgCl}_{2} 50 \mathrm{mM}, 1.5 \mu \mathrm{L}$ dNTP $1.25 \mathrm{mM}$ (Invitrogen, São Paulo, Brazil), $1 \mu \mathrm{L}$ of each primer $10 \mu \mathrm{M}, 0.1 \mu \mathrm{L}$ Taq DNA polymerase (Invitrogen) $5 \mathrm{U} / \mu \mathrm{L}$ and $1.5 \mu \mathrm{L}$ of genomic DNA. The conditions for amplification were $5 \mathrm{~min}$ at $95^{\circ} \mathrm{C}$ followed by 35 cycles of $30 \mathrm{~s}$ at $95^{\circ} \mathrm{C}, 30 \mathrm{~s}$ at the annealing temperature (see table 1), $5 \mathrm{~s}$ at $72^{\circ} \mathrm{C}$, and a final extension time of $5 \mathrm{~min}$ at $72^{\circ} \mathrm{C}$. The amplification products were separated in $6 \%$ denaturing polyacrylamide gel and visualized by silver nitrate staining, photographed, and analysed using the Kodak Digital Science program Eastman Kodak Company, Rochester, USA. Allele scoring was done using the 10-bp DNA Ladder (Invitrogen, São Paulo, Brazil) as size standard.

Among the 25 tested primer pairs, 11 loci were highly polymorphic (GenBank accession numbers JQ246359 to JQ246369). The allele number varied from 4 (Asty12) to 11 (Asty21) by locus; the value of expected heterozygosity varied from 0.64 (Asty12) to 0.88 (Asty13), and three loci showed deviation from the Hardy-Weinberg equilibrium (HWE) $(P<0.01)$ (table 1). They were calculated using GENALEX v6.1 software (Peakall and Smouse 2007). Pairwise tests for linkage disequilibrium among loci were calculated using GENEPOP 3.3 package (Raymond and Rousset 1995), and were nonsignificant. Micro-Checker (Van Oosterhout et al. 2004) was used to verify possible causes of HWE departures, and the analysis showed no evidence of stuttering, allelic dropout, or null alleles as a possible cause of HWE departures.

Cross-species amplification was investigated in 10 additional species of the same family (table 2). All 11 primers analysed revealed a high level (89\%) of cross-amplification in species of Astyanax, 43\% of which were polymorphic. On the other hand, with noncongeneric species (Salminus brasiliensis, Brycon amazonicus and B. hilarii), the crossamplification did not show positive results. Barbará et al. (2007) revealed that the transferability for fish species can be around $70 \%$ in congeners, lowering to $60 \%$ among

Table 1. Description of microsatellite loci and primer sequences in Astyanax altiparanae.

\begin{tabular}{|c|c|c|c|c|c|c|c|c|c|}
\hline & Primer sequence $\left(5^{\prime}-3^{\prime}\right)$ & Repeat motif & Lenght (bp) & $T_{\mathrm{a}}\left({ }^{\circ} \mathbf{C}\right)$ & $n$ & $A$ & $H_{\mathrm{o}}$ & $H_{\mathrm{e}}$ & $F_{\text {is }}$ \\
\hline Asty 4 & $\begin{array}{l}\text { GGTCACTGGAGGACAGATGTT } \\
\text { GGCATGTGCTTGAATGGA }\end{array}$ & $(\mathrm{AC})_{17}$ & 200 & 53 & 31 & 5 & 0.852 & 0.754 & $-0,129$ \\
\hline Asty 11 & $\begin{array}{l}\text { TAAATCTATAAAGTCACCAT } \\
\text { TTTGTTTTTCTGCCGCTGTTT }\end{array}$ & $(\mathrm{AC})_{12}$ & 151 & 50 & 32 & 9 & 0.630 & 0.837 & 0,248 \\
\hline Asty 12 & $\begin{array}{l}\text { AGACACAATCAGCCGCCGAAATG } \\
\text { ATCCCCTCTCCACAACCCAACACA }\end{array}$ & $(\mathrm{GT})_{8}$ & 163 & 58 & 25 & 4 & 0.742 & 0.638 & $-0,162$ \\
\hline Asty 13 & $\begin{array}{l}\text { AAATGGGTGCAAGCAACG } \\
\text { TGCCTGTCTGTAAGCATGTG }\end{array}$ & $(\mathrm{GT})_{8}$ & 160 & 58 & 25 & 10 & 0.563 & 0.877 & $0,359^{*}$ \\
\hline Asty 15 & $\begin{array}{l}\text { CAACTTTTACTTAAAACCTGC } \\
\text { ATGGGTCTTTACTGCTGAATGTAT }\end{array}$ & $(\mathrm{AC})_{17}-(\mathrm{CT})_{6}$ & 212 & 50 & 33 & 6 & 0.500 & 0.773 & $0,353^{*}$ \\
\hline Asty 16 & $\begin{array}{l}\text { AAAGTAAAGGGCATCTGTGGAGAA } \\
\text { AGAGGGCATCATTGTACATTTTTG }\end{array}$ & $(\mathrm{AC})_{10}$ & 165 & 52 & 32 & 8 & 0.769 & 0.860 & 0,106 \\
\hline Asty 21 & $\begin{array}{l}\text { TTTATGGGGACCGTGAGATGTGC } \\
\text { CAGGGGCAGCGGTGATACCT }\end{array}$ & $(\mathrm{CA})_{9}$ & 150 & 57 & 24 & 11 & 0.500 & 0.852 & $0,413^{*}$ \\
\hline Asty 23 & $\begin{array}{l}\text { TCAATGGAACCTATGGACAAC } \\
\text { GTGGGAAGTAGCCTAATAAATA }\end{array}$ & $(\mathrm{CA})_{12}$ & 160 & 52 & 30 & 6 & 0.600 & 0.743 & 0,193 \\
\hline Asty 24 & $\begin{array}{l}\text { AGACCAAACACTAGGGCTCAG } \\
\text { TTCGTCAATCTTCTTTCACTCTT }\end{array}$ & $(\mathrm{GT})_{9}$ & 139 & 52 & 32 & 7 & 0.677 & 0.800 & 0,153 \\
\hline Asty 26 & $\begin{array}{l}\text { CCCATTGATCCTGCCTCTAA } \\
\text { CAGTCCTGACACAGAGAT }\end{array}$ & $(\mathrm{GT})_{8}$ & 190 & 58 & 25 & 8 & 0.654 & 0.856 & 0,236 \\
\hline Asty 27 & $\begin{array}{l}\text { GCATTGTTCAGGTTGGGTCT } \\
\text { AAACGTGGTGAGAGGGAGTG }\end{array}$ & $(\mathrm{GT})_{8}$ & 150 & 58 & 25 & 9 & 0.667 & 0.809 & 0,176 \\
\hline
\end{tabular}

Intrapopulational analysis: $T_{\mathrm{a}}$, annealing temperature; $n$, number of individuals; $A$, allele number; $H_{\mathrm{o}}$, observed heterozygosity; $H_{\mathrm{e}}$, expected heterozygosity; $F_{\text {is }}$, endogamy index. * Loci that displayed significant deviations from Hardy-Weinberg equilibrium $(P<0.01)$. 
Table 2. Cross-amplification of the 11 polymorphic loci in seven species of Astyanax and three others species of Characidae.

\begin{tabular}{|c|c|c|c|c|c|c|c|c|c|c|c|}
\hline \multirow[b]{2}{*}{ Species } & \multicolumn{11}{|c|}{ Primer - Asty } \\
\hline & 4 & 11 & 12 & 13 & 15 & 16 & 21 & 23 & 24 & 26 & 27 \\
\hline Astyanax paranae & $\mathrm{P}$ & M & $\mathrm{P}$ & M & $\mathrm{P}$ & M & $\mathrm{P}$ & M & $\mathrm{P}$ & M & M \\
\hline A. bockmanni & - & $\mathrm{P}$ & $\mathrm{P}$ & - & $\mathrm{P}$ & $\mathrm{M}$ & $\mathrm{P}$ & $\mathrm{P}$ & $\mathrm{P}$ & $\mathrm{P}$ & $\mathrm{M}$ \\
\hline A. fasciatus & - & $\mathrm{P}$ & $\mathrm{P}$ & $\mathrm{P}$ & $\mathrm{P}$ & $\mathrm{P}$ & $\mathrm{P}$ & $\mathrm{P}$ & $\mathrm{P}$ & $\mathrm{P}$ & M \\
\hline A. jacuhiensis & $\mathrm{P}$ & $\mathrm{P}$ & $\mathrm{P}$ & $\mathrm{P}$ & $\mathrm{P}$ & $\mathrm{P}$ & $\mathrm{P}$ & $\mathrm{P}$ & $\mathrm{P}$ & $\mathrm{P}$ & $\mathrm{P}$ \\
\hline A. abramis & $\mathrm{M}$ & $\mathrm{P}$ & $\mathrm{M}$ & $\mathrm{P}$ & - & $\mathrm{M}$ & $\mathrm{M}$ & $\mathrm{P}$ & $\mathrm{P}$ & $\mathrm{P}$ & M \\
\hline A. schubarti & $\mathrm{M}$ & $\mathrm{P}$ & $\mathrm{P}$ & - & - & $\mathrm{M}$ & $\mathrm{M}$ & $\mathrm{P}$ & $\mathrm{M}$ & $\mathrm{M}$ & $\mathrm{M}$ \\
\hline A. ribeirae & $\mathrm{M}$ & $\mathrm{P}$ & $\mathrm{P}$ & $\mathrm{P}$ & - & $\mathrm{M}$ & $\mathrm{P}$ & $\mathrm{P}$ & $\mathrm{P}$ & $\mathrm{P}$ & M \\
\hline S. brasiliensis & M & - & M & - & M & M & M & $\mathrm{M}$ & M & M & - \\
\hline B. amazonicus & $\mathrm{M}$ & - & $\mathrm{M}$ & $\mathrm{M}$ & $\mathrm{M}$ & $\mathrm{M}$ & $\mathrm{M}$ & $\mathrm{M}$ & $\mathrm{M}$ & $\mathrm{M}$ & M \\
\hline B. hilarii & $\mathrm{M}$ & - & $\mathrm{M}$ & M & M & $\mathrm{M}$ & M & M & M & M & M \\
\hline
\end{tabular}

P, polymorphic; M, monomorphic; -, no amplification.

genera of the same family, which showed that the success of transferability of microsatellite loci were directly linked to phylogenetic relationship between the groups tested.

Astyanax spp. represent an excellent model group for studies of evolutionary mechanisms (Langecker et al. 1991; Jeffery 2001) because they are naturally distributed into structured groups (Garutti and Britski 2000), favouring vicariant processes responsible for the great diversity of Neotropical fishes (Castro 1999). Additionally, several Astyanax spp. are distributed in species complexes, such as bimaculatus, fasciatus and scabripinnis (Moreira-Filho and Bertolo 1991; Fernandes and Martins-Santos 2004; Artoni et al. 2006), which are abundant in rivers and other aquatic habitats throughout the Neotropical region (Reis et al. 2003). Consequently, the results obtained here reinforce the applicability of the microsatellites for parentage population genetic and studies in this heterogeneous group of fishes.

\section{Acknowledgements}

This work was supported by grants from Fundação de Amparo à Pesquisa do Estado de São Paulo (FAPESP), Conselho Nacional de Desenvolvimento Científico e Tecnológico (CNPq) and Coordenação de Aperfeiçoamento de Pessoal de Nível Superior (CAPES). We are grateful to Laboratório de Análise Genética e Molecular, CBMEG - UNICAMP, for help with microsatellite library enrichment.

\section{References}

Agostinho A. A., Gomes L. C. and Pelicice F. M. 2007 Ecologia e manejo de recursos pesqueiros em reservatórios do Brasil. EDUEM, Maringá, Brazil.

Artoni R. F., Shibatta O. A., Gross M. C., Schneider C. H., Almeida M. C., Vicari M. R. and Bertollo L. A. C. 2006 Astyanax aff. fasciatus Cuvier, 1819 (Teleostei; Characidae): evidences of a species complex in the upper rio Tibagi Basin (Paraná, Brazil). Neotrop. Ichthyol. 4, 197-202.

Barbará T., Palma-Silva C., Paggi G. M., Bered F., Fay M. F. and Lexer C. 2007 Cross-species transfer of nuclear microsatellite markers: potential and limitations. Mol. Ecol. 16, 3759-3767.
Billotte N., Lagoda P. J. L., Risterucci A. M. and Baurens F. C. 1999 Microsatellite-enriched libraries: applied methodology for the development of SSR markers in tropical crops. Fruits 54, 277-288.

Castro R. M. C. 1999 Evolução da ictiofauna de riachos sulamericanos: Padrões gerais e possíveis processos causais. In Ecologia de Peixes de Riachos (ed. E. P. Caramashi, R. Mazzoni and P. R. Peres-Neto), pp. 139-155. PPGE-UFRJ, Rio de Janeiro, Brazil.

Fernandes C. A. and Martins-Santos I. C. 2004 Cytogenetic studies in two populations of Astyanax altiparanae (Pisces, Characiformes). Hereditas 141, 328-332.

Froese R. and Paulay D. 2010 FishBase. World Wide Web electronics publication, http://www.fishbase.org/. (Acessed 03 November 2010).

Garutti V. and Britski H. A. 2000 Descrição de uma nova espécie de Astyanax (Telostei, Characidae) da bacia do Alto Paraná e considerações sobre as demais espécies do gênero na bacia. Comun. Mus. Ciênc. Ser. Zool. PUCRS 13, 65-88.

Javonillo R., Malabarba L. R., Weitzman S. H. and Burns J. R. 2010 Relationships among major lineages of characid fishes (Teleostei: Ostariophysi: Characiformes), based on molecular sequence data. Mol. Phyl. Evol. 54, 498-511.

Jeffery W. R. 2001 Cavefish as a model system in evolutionary developmental biology. Dev. Biol. 231, 1-12.

Langecker T. G., Wilkens H. and Junge P. 1991 Introgressive hybridization in the Pachon cave population of Astyanax fasciatus. Ichthyol. Explor. Freshw. 2, 209-212.

Leuzzi M. S. P., Almeida F. S., Orsi M. L. and Sodré L. M. K. 2004 Analysis by RAPD of the genetic structure of Astyanax altiparanae (Pisces, Characiformes) in reservoirs on the Paranapanema River, Brazil. Genet. Mol. Biol. 27, 355362.

Mirande J. M. 2010 Phylogeny of the family Characidae (Teleostei: Characiformes): from characters to taxonomy. Neotrop. Ichthyol. 8, 385-568.

Moreira-Filho O. and Bertollo L. A. 1991 Astyanax scabripinnis (Pisces: Characidae), a species complex. Rev. Bras. Genet. 14, 331-357.

Oliveira E. J., Pádua J. G., Zucchi M. I., Vencovsky R. and Vieira M. L. C. 2006 Origin, evolution and genome distribution of microsatellites. Genet. Mol. Biol. 2, 294-307.

Peakall R. and Smouse P. E. 2007 GENALEX 6.1: genetic analysis in Excel. Population genetic software for teaching and research. Australian National University, Canberra, Australia, (http://www.anu.edu.au/BoZo/GenAlEx). 
Peres M. D., Vasconcelos M. S. and Renesto E. 2005 Genetic variability in Astyanax altiparanae Garutti and Britski, 2000 (Teleostei, Characidae) from the Upper Paraná River basin, Brazil. Genet. Mol. Biol. 28, 717-724.

Porto-Foresti F., Castilho-Almeida R. B., Senhorini J. A. and Foresti F. 2010 Biologia e criação do lambari-do-rabo-amarelo (Astyanax altiparanae). In Espécies nativas para piscicultura no Brasil (ed. B. Baldisserotto and L. C. Gomes), pp. 101-115. Editora UFSM, Santa Maria.

Prioli S. M. A. P., Prioli A. J., Júlio Jr H. F., Pavanelli C. S., Oliveira A. V., Carrer H. et al. 2002 Identification of Astyanax altiparanae (Teleostei, Characidae) in the Iguaçu River, Brazil, based on mitochondrial DNA and RAPD markers. Genet. Mol. Biol. 25, 421-430.
Raymond M. and Rousset F. 1995 Genepop (version 1.2): population genetics software for exact tests and ecumenicism. J. Her. 86, 248-249.

Reis R. E., Kullander S. O. and Ferraris C. J. 2003 Check list of the freshwater fishes of South and Central America. Edipucrs, Porto Alegre, Brazil.

Rosen S. and Skaletsky H. 2000 Primer3 on the WWW for general users and for biologist programmers. In Bioinformatics methods and protocols: methods in molecular biology (ed. S. Misener and S. A. Krawetz), pp. 365-386. Humana Press, Totowa, New Jersey, USA.

Van Oosterhout C., Hutchinson W. F. , Wills D. P. M. and Shipley P. 2004 Micro-checker: software for identifying and correcting genotyping errors in microsatellite data. Mol. Ecol. Notes 4, 535-538.

Received 28 October 2011, in final revised form 30 December 2011; accepted 4 January 2012

Published on the Web: 28 March 2012 